EL MUHASABA: Jurnal Akuntansi (e-Journal)

Volume 12 , No. 1, Tahun 2021

P ISSN: 2086-1249 ; E ISSN: 2442-8922

\title{
PENGARUH SANKSI PERPAJAKAN DAN KUALITAS PELAYANAN TERHADAP KEPATUHAN WAJIB PAJAK
}

\author{
Erika Zahra Afifah Syafira1, R. Nasution² \\ Universitas Singaperbangsa 1, Universitas Singaperbangsa 2 \\ Jl. HS. Ronggo Waluyo, Paseurjaya, Telukjambe Timur, \\ Karawang, Jawa Barat, 41361, Indonesia \\ e-mail: 1610631030104@students.unsika.ac.id 1
}

\begin{abstract}
The porpuse of this research is to know the impact of tax penalties and the quality of service on taxpayer's obedience. The data that used in this research is primary data that obtained through the distribution of questionnaires to sample that represent the criteria of the population. The population of this research is taxpayer of KPP Pratama Cikarang Selatan. As for the sample of this reaserch is 100 respondents, that determined by the slovin formula. The methods of this research for validity data is used validity test and reability test. To perevent any bias of use regretion models on research, then used a classical assumption test. The analysis technique that used is multiple regression analysis. For hypothetical test in this research used the t-test that is a partial test and F-test that is a simultaneous test. The result of this research is 1 . The tax penalties have a positive and significant impact on taxpayer's obedience 2. The quality of servis have a positive and significant impact in taxpayer's obedience. 3. The tax penalties and the quality of service have impact in taxpayer's obedience.
\end{abstract}

Keywords: Obedience; Taxpayer's; Tax Penalties; Quality of service

\begin{abstract}
Abstrak
Tujuan penelitian ini adalah untuk mengetahui pengaruh sanksi perpajakan dan kualitas pelayanan terhadap kepatuhan wajib pajak. Data yang digunakan pada penelitian ini adalah data primer yang diperoleh melalui penyebaran kuesioner kepada sampel yang mewakili kriteria dari populasi. Populasi penelitian ini adalah wajib pajak yang terdaftar di KPP Prama Cikarang Selatan. Adapun jumlah sampel dalam penelitian ini adalah 100 responden, yang ditentukan dengan rumus slovin. Metode penelitian untuk menguji keabsahan data penelitian ini menggunakan uji validitas dan reabilitas terhadap item kuesioner. Kemudian untuk mencegah adanya bias penggunaan model regresi pada penelitian maka melakukan uji asumsi klasik. Teknik analisis yang digunakan adalah teknik analisis regresi berganda. Untuk pengujian hipotesis penelitian ini menggunakan uji $t$ yakni pengujian hipotesis secara parsial atau sendiri-sendiri dan uji $\mathrm{F}$ yakni pengujian hipotesis secara simultan atau bersama-sama. Hasil penelitian ini adalah 1. Sanksi perpajakan berpengruh positif dan signifikan terhadap kepatuhan wajib pajak. 2 . Kualitas pelyanan berpengaruh positif dan signifikan terhadap kepatuhan wajib pajak, 3. Sanksi perpajakan dan kualitas pelayanan berpengaruh positif dan signifikan secara simultan terhadap kepatuhan wajib pajak.
\end{abstract}

Kata kunci: Kepatuhan; Wajib Pajak; Sanksi Perpajakan; Kualitas Pelayanan 
Erika Zahra Afifah Syafira Nasution: Pengaruh Sanksi Perpajakan dan Kualitas Pelayanan Terhadap Kepatuhan Wajib Pajak

\section{PENDAHULUAN}

Pajak merupakan konstribusi berupa iuran yang bersifat memaksa bagi masyarakat yang telah memenuhi syarat objektif dan subjektif sehingga diwajibkan membayar pajak. Masyarakat yang diwajibkan membayar pajak disebut wajib pajak. Pembayaran pajak merupakan suatu bentuk realisasi dari kontribusi masyarakat atau wajib pajak dengan cara membiayai pengeluaran negara dalam rangka mewujudkan kemakmuran rakyat Indonesia melalui pembangunan nasional.

Pajak memiliki dasar hukum yang kuat yakni tertera dalam Pasal 23A UUD 1945 yang berbunyi "Pajak dan pungutan lain yang bersifat memaksa untuk keperluan negara diatur dengan undang-undang". Maka bagi wajib pajak yang tidak patuh atau melanggar akan mendapatkan sanksi perpajakan. Oleh karena itu wajib pajak dituntut untuk mematuhi segala peraturan yang telah ditetapkan berdasarkan undang-undang perpajakan. Terlebih jika peningkatan kepatuhan wajib pajak tinggi maka semakin tinggi pula tingkat pembayaran pajak yang dilakukan oleh wajib pajak, sehingga pendapatan negara yang diterima pun semakin meningkat.

Salah satu indikator kepatuhan wajib pajak yaitu dengan melihat tingkat kepatuhan formal berupa kewajiban penyampaian dan pelaporan SPT sesuai dengan jadwal yang telah ditentukan. Penyampaian dan pelaporan SPT dapat dilihat melalui realisasi SPT. Berikut data Realisasi SPT yang dilakukan oleh wajib pajak periode tahun 2015-2020 di KPP Pratama Cikarang Selatan.

Tabel 1. Realisasi SPT Wajib Pajak tahun 2015-2019

\begin{tabular}{|c|c|c|c|c|c|c|}
\hline \multirow{2}{*}{\multicolumn{2}{|c|}{ Keterangan }} & \multicolumn{5}{|c|}{ Tahun } \\
\hline & & \multirow{2}{*}{$\begin{array}{c}2015 \\
6.266\end{array}$} & \multirow{2}{*}{$\begin{array}{l}2016 \\
6.588\end{array}$} & \multirow{2}{*}{$\begin{array}{l}2017 \\
6.426\end{array}$} & \multirow{2}{*}{$\begin{array}{c}2018 \\
7.862\end{array}$} & \multirow{2}{*}{$\begin{array}{l}2019 \\
7.844\end{array}$} \\
\hline \multirow{3}{*}{ WP Badan } & Wajib SPT & & & & & \\
\hline & Realisasi SPT & 3.601 & 3.317 & 4.254 & 4.964 & 5.783 \\
\hline & Selisih & 2.665 & 3.271 & 2.172 & 2.898 & 2.061 \\
\hline \multirow{3}{*}{$\begin{array}{c}\text { WP OP } \\
\text { Non } \\
\text { Karyawan }\end{array}$} & Wajib SPT & 4.961 & 4.998 & 4.722 & 4.498 & 5.573 \\
\hline & Realisasi SPT & 706 & 1.185 & 1.462 & 3.088 & 2.987 \\
\hline & Selisih & 4.255 & 3.813 & 3.260 & 1.410 & 2.586 \\
\hline \multirow{3}{*}{$\begin{array}{c}\text { WP OP } \\
\text { Karyawan }\end{array}$} & Wajib SPT & 96.297 & 96.878 & 73.728 & 82.466 & 78.468 \\
\hline & Realisasi SPT & 43.589 & 45.517 & 44.667 & 45.558 & 47.245 \\
\hline & Selisih & 52.708 & 51.361 & 29.061 & 36.908 & 31.223 \\
\hline
\end{tabular}

Sumber: KPP Pratama Cikarang Selatan (data diolah), 2020

Dari tabel 1 tersebut dapat diketahui bahwa realisasi SPT di KPP Pratama Cikarang Selatan baik WP Badan, WP OP Non Karyawan, maupun WP OP Karyawan setiap tahunnya selalu terjadi selisih antara wajib SPT dan realisasi SPT. Dimana selisih tersebut memiliki sifat yang fluktuatif dan cenderung mengalami penurunan. Yang artinya jika ditinjau secara keseluruhan melalui selisih realisasi SPT dan wajib SPT, kepatuhan formal Wajib Pajak di KPP Pratama Cikarang Selatan setiap tahunnya selalu mengalami perkembangan 
Erika Zahra Afifah Syafira Nasution: Pengaruh Sanksi Perpajakan dan Kualitas Pelayanan Terhadap Kepatuhan Wajib Pajak

yang cukup signifikan. Namun meskipun demikian masih banyak WP yang belum patuh akan penyampaian dan pelaporan SPT tersebut terutama WP OP Karyawan.

Hal itu menimbulkan fenomena, pasalnya bagi wajib pajak yang tidak patuh atau melanggar peraturan perundang-undangan perpajakan akan dikenakan sanksi. Dalam hal ini, bagi wajib pajak yang tidak patuh dalam penyampaian SPT akan dikenakan sanksi administrasi berupa denda sebagaimana telah diatur dalam pasal 7 ayat (1) Undang-Undang Ketentuan Umum Perpajakan (UU KUP).

Menurut penelitian terdahulu Pranata (2015) bahwa kualitas pelayanan dan sanksi perpajakan berpengaruh positif terhadap kepatuhan wajib pajak yang berarti apabila semakin baik kualitas pelayanan dan penerapan sanksi secara tegas maka kepatuhan wajib pajak akan semakin baik. Begitupun hasil penilitian Susmita (2016) menyatakan bahwa kualitas pelayanan dan sanksi perpajakan berpengaruh positif terhadap kepatuhan wajib pajak. Kemudian penelitian yang dilakukan oleh Akbar (2019) juga menyatakan bahwa sanksi pajak berpengaruh pada kepatuhan wajib pajak. Hal tersebut juga dikemukakan oleh Agustini (2019) bahwa sanksi pajak berpengaruh positif terhadap kepatuhan wajib pajak.

Meskipun hasil penelitian terdahulu diatas menyatakan terdapat pengaruh antara sanksi pajak dan kualitas pelayanan terhadap kepatuhan wajib pajak, hal itu tidak terjadi pada penelitian yang dilakukan Patmasari (2016) yang menyatakan bahwa kualitas pelayanan dan sanksi perpajakan tidak berpengaruh signifikan terhadap kepatuhan wajib pajak. Didukung oleh Nafiah (2018) yang menyatakan bahwa kualitas pelayanan tidak berpengaruh signifikan terhadap kepatuhan wajib pajak. Sedangkan pernyataan bahwa sanksi pajak tidak berpengaruh terhadap kepatuhan wajib pajak merupakan hasil penelitian oleh Muhamad (2019).

\section{KAJIAN PUSTAKA}

Akuntansi adalah seni pencatatan, penggolongan, pengikhtisaran, dan pelaporan atas suatu transaksi dengan sistematis dan memenuhi standar yang diakui umum (Bahri, 2016:2).Akuntansi merupakan sistem informasi yang menghasilkan laporan mengenai aktivitas ekonomi dan kondisi suatu perusahaan kepada pihak-pihak yang berkepentingan (Rahmawaty, 2017: 2).

Pajak ialah iuran rakyat kepada kas negara yang dapat dipaksakan berdasarkan undang-undang, dimana pajak tersebut digunakan untuk membayar keperluan umum negara, namun timbal balik yang diperoleh dari pajak tidak dapat ditujukan atau dirasakan langsung oleh wajib pajak (Mardiasmo, 2016: 3). 
Erika Zahra Afifah Syafira Nasution: Pengaruh Sanksi Perpajakan dan Kualitas Pelayanan Terhadap Kepatuhan Wajib Pajak

\section{Sanksi Perpajakan}

Sanksi perpajakan merupakan suatu akibat yang disebabkan oleh tindakan dalam melanggar peraturan perpajakan, dimana pengenaan sanksi ditujukan untuk meningkatkan kepatuhan wajib pajak (Patmasari, 2016: 549).

Adapun indikator sanksi perpajakan dapat dilihat berdasarkan ketepatan dan keadilan penerapan sanksi perpajakan. Dampak apabila penerapan sanksi pajak tidak tepat dan tidak profesional maka rasa keadilan wajib pajak akan tercederai. Hal itu juga dapat menimbulkan dampak negatif dimana wajib pajak akan memanfaatkan peluang untuk menghindari pajak dan menunjukan ketidakpatuhannya terhadap peraturan perundang-undangan perpajakan (Simanjuntak, 2012: 89).

\section{Kualitas Pelayanan}

Menurut Cronin, kualitas pelayanan adalah penilaian atas harapan yang diinginkan pelanggan terhadap kinerja aktual dari suatu penyediaan layanan (Pranata, 2015: 460).

Dalam meningkatkan kualitas dan memberikan pelayanan yang prima terhadap wajib pajak diperlukan standarisasi yang diterapkan oleh kantor pelayanan pajak. Dimana KPP berkewajiban memenuhi hak wajib pajak sehingga adanya rasa kepuasan akan pelayanan tersebut. Dengan adanya standarisasi pelayanan diharapkan terwujudnya pelayanan prima dan keseragaman dalam pemberian pelayanan kepada Wajib Pajak yang diselenggarakan di tempat pelayanan terpadu kantor pelayanan pajak. Peraturan Direktur Jendral Pajak PER- 27/PJ/2016 kemudian diubah menjadi PER02/PJ/2017 tentang standar pelayanan terpadu Kantor Pelayanan Pajak (KPP) digunakan sebagai pedoman bagi tempat pelayanan terpadu untuk merealisasikan pelayanan prima.

\section{Kepatuhan Wajib Pajak}

Kepatuhan wajib pajak merupakan kesediaan dari wajib pajak untuk memenuhi kewajibannya tanpa perlu dilakukan pemeriksaan, investigasi seksama, peringatan atau ancaman dan penerapan sanksi hukum maupun administrasi (Sabet, 2020: 38). Adapun Indikator Kepatuhan Wajib Pajak menurut Simanjutak (2012: 103) antara lain:

1) Aspek ketepatan waktu dalam pelaporan SPT sesuai dengan ketentuan yang berlaku

2) Aspek income atau penghasilan wajib pajak dalam kesediaan membayar kewajiban angsuran Pajak Penghasilan atau PPh sesuai ketentuan yang berlaku

3) Aspek law enforcemen atau pengenaan sanksi yaitu kesediaan membayar tunggakan pajak yang ditetapkan berdasarkan SKP atau Surat Ketetapan Pajak sebelum jatuh tempo

4) Aspek lainnya seperti aspek pembayaran dan aspek kewajiban pembukuan 
Erika Zahra Afifah Syafira Nasution: Pengaruh Sanksi Perpajakan dan Kualitas Pelayanan Terhadap Kepatuhan Wajib Pajak

\section{HIPOTESIS}

Hipotesis adalah kebenaran atau dugaan sementara mengenai apa saja yang sedang diamati dalam memahaminya dan masih harus diuji (Rochaety, 2019: 23). Hipotesis penelitian ini diambil berdasarkan kerangka pemikiran yang digambarkan pada ilustrasi Gambar 1 dibawah ini:

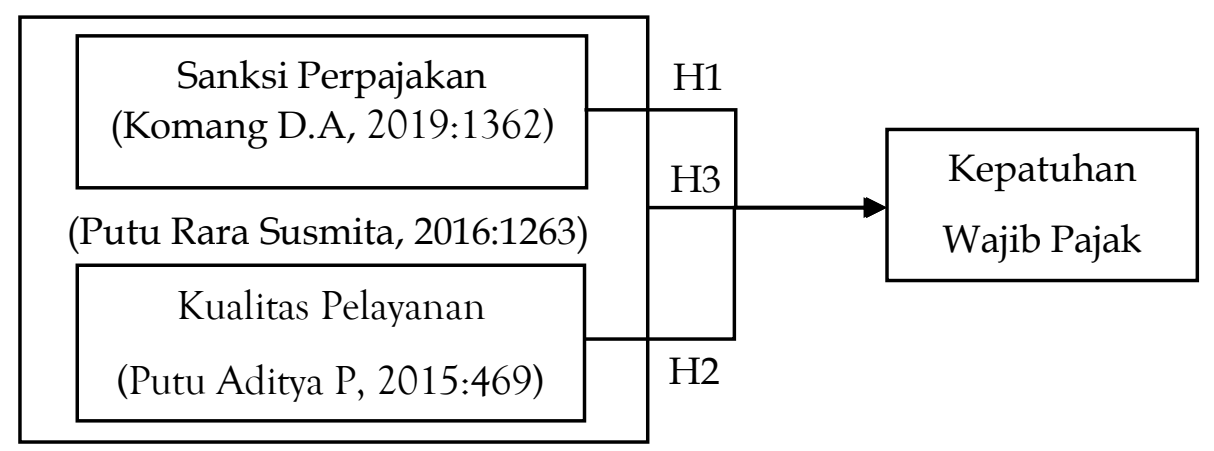

\section{Gambar 1. Kerangka Pemikiran \\ Sumber: Penulis, 2020}

Keterangan:

H1: Sanksi Pajak berpengaruh positif terhadap Kepatuhan Wajib Pajak

H2: Kualitas Pelayanan berpengaruh positif terhadap Kepatuhan Wajib Pajak

H3: Sanksi Pajak dan Kualitas Pelayanan berpengaruh positif terhadap Kepatuhan Wajib Pajak

Berdasarkan kerangka pemikiran tersebut maka hipotesisi penelitian ini adalah:

H1 : Sanksi Pajak berpengaruh terhadap kepatuhan Wajib Pajak

H2 : Kualitas Pelayanan berpengaruh terhadap kepatuhan Wajib Pajak

H3 : Sanksi Pajak dan Kualitas Pelayanan berpengaruh terhadap kepatuhan Wajib Pajak

\section{METODE}

Metode penelitian pada penelitian ini adalah penelitian dasar (Basic Research) dengan submit penelitian deduktif yakni dengan menarik kesimpulan penelitian apakah mendukung atau menolak hipotesis yang dikembangkan dari telaah teoritis sebagai hasil pengujian data (Rochaety, 2019:11).

Variabel penelitian ini ada 3 yaitu sanksi perpajakan (X1) dan kualitas pelayanan $(\mathrm{X} 2)$ sebagai variabel independen, dan kepatuhan wajib pajak (Y) sebagai variabel dependen.

Populasi penelitian adalah wajib pajak yang terdaftar di KPP Pratama Cikarang Selatan. Sampel yang diperoleh sebanyak 100 wajib pajak, yang ditentukan dengan rumus Slovin. Alat yang digunakan pada penelitian ini adalan Analisis Regresi Berganda. Teknik pengumpulan data pada penelitian ini menggunakan data primer berupa data kuesioner yang disebar kepada sampel atau responden yang mewakili kriteria dari populasi. Jenis kuesioner yang 
Erika Zahra Afifah Syafira Nasution: Pengaruh Sanksi Perpajakan dan Kualitas Pelayanan Terhadap Kepatuhan Wajib Pajak

digunakan merupakan daftar pertanyaan tertutup dimana responden hanya memberikan tanda yang sesuai. Adapun skala yang digunakan dalam penelitian ini yaitu skala likert.

Dalam penelitian ini uji untuk mengukur ketepatan dan kecermatan tes dalam menjalankan fungsi pengukurannya maka dilakukan uji validitas. Semakin tinggi validitas suatu tes maka tingkat tepat sasarannya semakin baik. Sedangkan untuk mengetahui bahwa hasil penelitian memiliki instrument pengukuran yang baik dan reliabel maka dilakukan uji reliabelitas. Kemudian melakukan uji asumsi klasik untuk menghindari munculnya bias dalam analisis data serta menghindari kesalahan spesifikasi model regresi yang digunakan.

HASIL DAN PEMBAHASAN

Uji Validitas

Tabel 2. Uji Validitas Pearson Sanksi Perpajakan (X1)

\begin{tabular}{ccccc}
\hline No Item & $r_{\text {hitung }}$ & $r_{\text {tabel }} 5 \%(\mathrm{df}=100-2)$ & Sig. & Kriteria \\
\hline 1 & 0.777 & 0.197 & 0.05 & Valid \\
\hline 2 & 0.732 & 0.197 & 0.05 & Valid \\
\hline 3 & 0.755 & 0.197 & 0.05 & Valid \\
\hline 4 & 0.747 & 0.197 & 0.05 & Valid \\
\hline 5 & 0.697 & 0.197 & 0.05 & Valid \\
\hline \multicolumn{2}{r}{ Total X1 $=1$} & & & \\
\hline Sig. (2-tailed) $=0.000$ & & &
\end{tabular}

Sumber: Hasil Pengolahan Data SPSS (2020)

Tabel 3. Uji Validitas Pearson Kualitas Pelayanan (X2)

\begin{tabular}{ccccc}
\hline No Item & $r_{\text {hitung }}$ & $r_{\text {tabal }} 5 \%(\mathrm{df}=100-2)$ & Sig. & Kriteria \\
\hline 1 & 0.795 & 0.197 & 0.05 & Valid \\
\hline 2 & 0.732 & 0.197 & 0.05 & Valid \\
\hline 3 & 0.807 & 0.197 & 0.05 & Valid \\
\hline 4 & 0.765 & 0.197 & 0.05 & Valid \\
\hline 5 & 0.792 & 0.197 & 0.05 & Valid \\
\hline \multicolumn{2}{l}{ Total X2 $=1$} & & & \\
\hline Sig. (2-tailed) $=0.000$ & & &
\end{tabular}

Sumber: Hasil Pengolahan Data SPSS (2020)

Tabel 4. Uji Validitas Pearson Kepatuhan Wajib Pajak (Y)

\begin{tabular}{ccccc}
\hline \multirow{2}{*}{ No Item } & $r_{\text {hitung }}$ & $r_{\text {tab } \boldsymbol{\theta}} 5 \%(\mathrm{df}=100-2)$ & Sig. & Kriteria \\
\hline 1 & 0.756 & 0.197 & 0.05 & Valid \\
\hline 2 & 0.722 & 0.197 & 0.05 & Valid \\
\hline
\end{tabular}


Erika Zahra Afifah Syafira Nasution: Pengaruh Sanksi Perpajakan dan Kualitas Pelayanan Terhadap Kepatuhan Wajib Pajak

\begin{tabular}{ccccc}
\hline 3 & 0.742 & 0.197 & 0.05 & Valid \\
\hline 4 & 0.679 & 0.197 & 0.05 & Valid \\
\hline 5 & 0.527 & 0.197 & 0.05 & Valid \\
\hline \multicolumn{2}{c}{ Total Y $=1$} \\
\hline \multicolumn{2}{l}{ Sig. (2-tailed) $=0.000$} \\
\hline
\end{tabular}

Sumber: Hasil Pengolahan Data SPSS (2020)

Pengambilan keputusan berdasarkan Nilai $r$ hitung dan $r$ tabel

Pada penelitian ini diperoleh $r_{t a b_{\theta l}}$ dari nilai df $=100-2$, sehingga $r_{t a b_{\theta}}$ pada penelitian ini sebesar 0.197

Berdasarkan output "Correlation" dapat diketahui bahwa baik pada tabel 2 Uji Validitas Sanksi Perpajakan (X1), tabel 1.3 Uji Validitas Kualitas Pelayanan (X2), dan tabel 4 Uji Validitas Kepatuhan Wajib Pajak (Y) memiliki nilai r hitung $>\mathrm{r}$ tabel . Sehingga dapat disimpulkan pengukuran yang digunakan pada kuesioner dinyatakan valid.

Pengambilan keputusan berdasarkan Nilai Signifikan

Berdasarkan nilai Sig atau signifikan pada tabel 2 Uji Validitas Sanksi Perpajakan (X1), 3 Uji Validitas Kualitas Pelayanan (X2), dan 4 Uji Validitas Kepatuhan Wajib Pajak (Y) mengindikasi bahwa nilai Sig bernilai positif dan kurang dari 0.05, maka pengukuran pada kuesioner valid.

\section{Uji Reabilitas}

Tabel 5. Reabilitas Statistic

\begin{tabular}{ccc}
\hline Keterangan & Cronbach's Alpha & N of Items \\
\hline Sanksi Perpajakan (X1) & 0.804 & 5 \\
\hline Kualitas Pelayanan (X2) & 0.829 & 5 \\
\hline Kepatuhan Wajib Pajak (Y) & 0.648 & 5
\end{tabular}

Sumber: Hasil Pengolahan Data (2020)

Dari tabel 5 dapat diketahui nilai Cronbach's Alpha baik pada variabel X1 (Sanksi Perpajakan), X2 (Kualitas Pelayanan), dan Y (Kepatuhan Wajib Pajak) > 0.600, sehingga dapat disimpulkan bahwa instrument pada penelitian ini mengindikasikan reliabel atau terpercaya.

\section{Uji Asumsi Klasik}

Uji asumsi klasik terdiri dari uji normalitas, uji multikolinearitas, dan uji heteroskedastisitas.

\section{Uji Normalitas}

Berdasarkan tabel 6 hasil normalitas One-Sample Kolmogorof-Smirnov dapat diketahui nilai signifikan sebesar $0.230>0.05$, maka dapat disimpulkan bahwa model regresi linier variabel dependen dan variabel independen keduanya memiliki distribusi yang normal. 
Erika Zahra Afifah Syafira Nasution: Pengaruh Sanksi Perpajakan dan Kualitas Pelayanan Terhadap Kepatuhan Wajib Pajak

Tabel 6. Uji Normalitas One-Sample Kolmogorof-Smirnov

\begin{tabular}{llr}
\hline \multicolumn{3}{c}{ One-Sample Kolmogorov-Smirnov Test } \\
\hline & \multicolumn{1}{c}{$\begin{array}{c}\text { Unstandardized } \\
\text { Residual }\end{array}$} \\
\hline $\mathrm{N}$ & \multicolumn{1}{c}{100} \\
\hline Normal Parametersa & Std. Deviation & .0000000 \\
\cline { 2 - 3 } & Absolute & .1 .40199651 \\
\cline { 2 - 3 } & Positive & .104 \\
\cline { 2 - 3 } & Negative & -.096 \\
\hline Kolmogorov-Smirnov Z & & 1.040 \\
\hline Asymp. Sig. (2-tailed) & & .230 \\
\hline
\end{tabular}

Sumber: Hasil Pengolahan Data SPSS (2020)

Uji Multikolinearitas

Tabel 7 Uji Mulikolinearitas

\begin{tabular}{|c|c|c|c|c|c|c|c|}
\hline \multicolumn{8}{|c|}{ Coefficients ${ }^{a}$} \\
\hline \multirow[b]{2}{*}{ Model } & \multicolumn{2}{|c|}{$\begin{array}{l}\text { Unstandardized } \\
\text { Coefficients }\end{array}$} & \multirow{2}{*}{$\begin{array}{c}\begin{array}{c}\text { Standardized } \\
\text { Coefficients }\end{array} \\
\text { Beta }\end{array}$} & \multirow[t]{2}{*}{$\mathrm{t}$} & \multirow[t]{2}{*}{ Sig. } & \multicolumn{2}{|c|}{$\begin{array}{l}\text { Collinearity } \\
\text { Statistics }\end{array}$} \\
\hline & B & Std. Error & & & & Tolerance & VIF \\
\hline 1 (Constant) & 5.011 & 1.459 & & 3.435 & .001 & & \\
\hline $\begin{array}{l}\text { Sanksi } \\
\text { Perpajakan }\end{array}$ & .283 & .076 & .308 & 3.721 & .000 & .722 & 1.386 \\
\hline $\begin{array}{l}\text { Kualitas } \\
\text { Pelayanan }\end{array}$ & .438 & .071 & .511 & 6.177 & .000 & .722 & 1.386 \\
\hline
\end{tabular}

a. Dependent Variable: Kepatuhan Wajib Pajak

\section{Sumber: Hasil Pengolahan Data SPSS (2020)}

Berdasarkan Tabel 7 dapat diketahui bahwa nilai Tolerance dan Varian Inflaction Factor (VIF) dengan nilai Cut off Tolerance $0.722>0.10$ dan nilai VIF $1.386<10$ maka dapat disimpulkan data tersebut tidak mengindikasi adanya multikolinearitas. 
Erika Zahra Afifah Syafira Nasution: Pengaruh Sanksi Perpajakan dan Kualitas Pelayanan Terhadap Kepatuhan Wajib Pajak

\section{Uji Heteroskedastisitas}

Tabel 8 Uji Heterokedastisitas

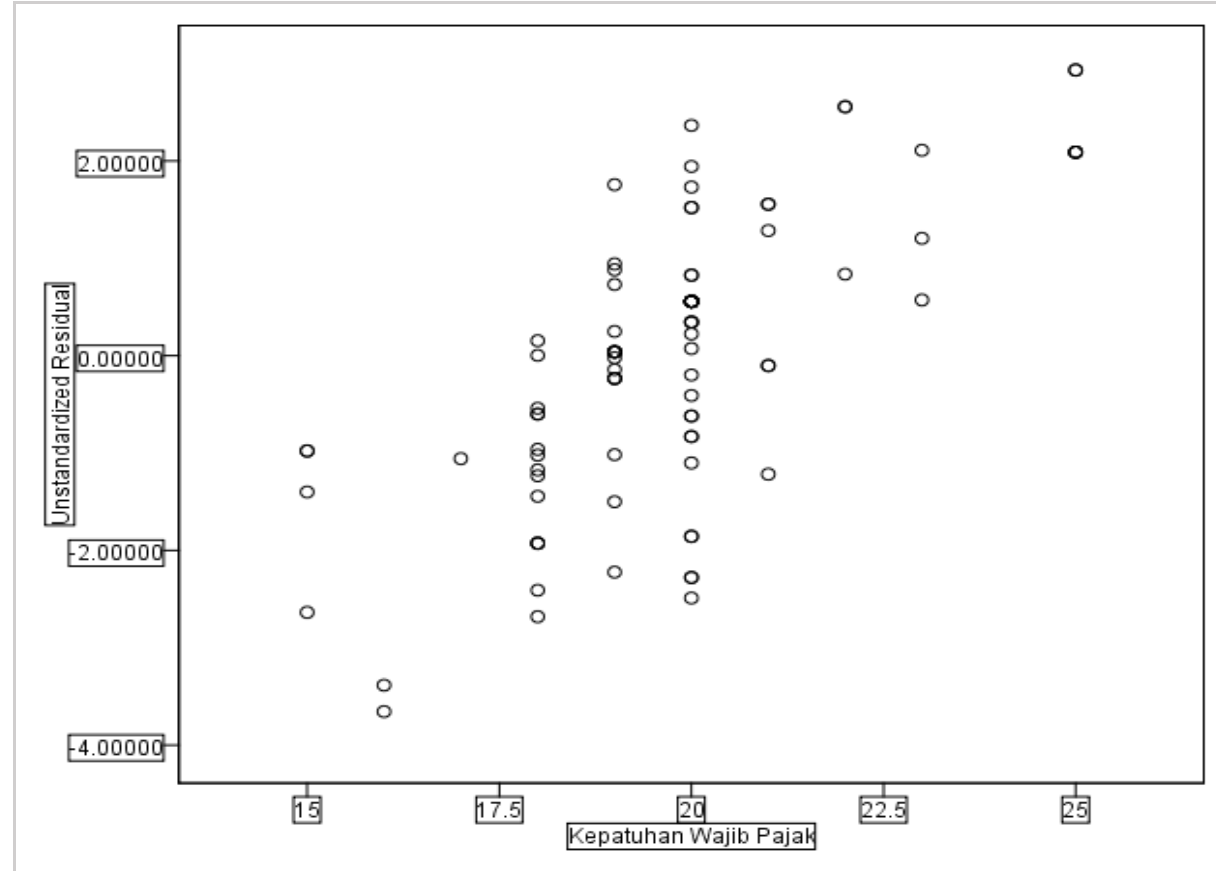

Sumber: Hasil Pengolahan Data SPSS (2020)

Berdasarkan tabel 8 dapat diketahui bahwa titik titik pada grafik Scatterplot membentuk garis diagonal maka dapat disimpulkan bahwa data pada penelitian tidak terjadi heteroskedatisitas.

\section{Analisis Regresi Berganda}

Tabel 9 Analisis Regresi Berganda

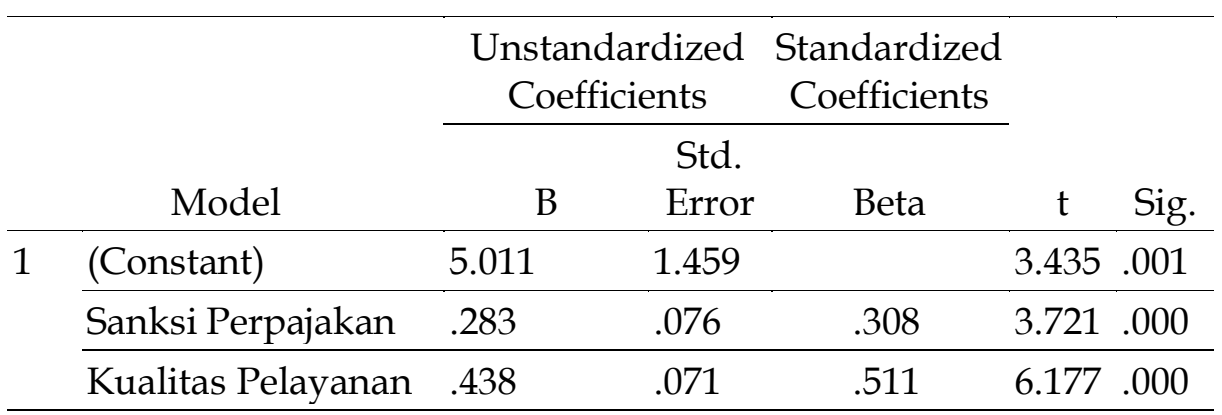

a. Dependent Variable: Kepatuhan Wajib Pajak

\section{Sumber: Hasil Pengolahan Data SPSS (2020)}

Berdasarkan tabel 9 dapat diketahui bahwa nilai konstanta (a) sebesar 5.011 dan nilai koefisien regresi sebesar 0.283 (X1) dan 0.438 (X2). Sehingga persamaan yang diperoleh adalah sebagai berikut:

$$
Y=5.011+0.283 x_{1}+0.438 x_{2}
$$

1) Nilai konstanta (a) positif sebesar 5.011 menunjukan variabel independen sanksi perpajakan dan kualitas pelayanan berpengaruh positif dan apabila sanksi perpajakan dan kualitas pelayanan naik atau berpengaruh maka kepatuhan wajib pajak pun akan naik atau mengalami peningkatan 
Erika Zahra Afifah Syafira Nasution: Pengaruh Sanksi Perpajakan dan Kualitas Pelayanan Terhadap Kepatuhan Wajib Pajak

2) Nilai koefisien regresi variabel sanksi perpajakan (X1) sebesar 0.283 yaitu jika sanksi perpajakan mengalami kenaikan maka kepatuhan wajib pajak akan mengalami peningkatan sebesar 0.283 atau $28,3 \%$

3) Nilai koefisien regresi variabel kualitas pelayanan $(X 2)$ sebesar 0.438 yaitu jika kualitas pelayanan mengalami kenaikan maka kepatuhan wajib pajak akan mengalami peningkatan sebesar 0.438 atau $43,8 \%$.

4)

Tabel 10 Koefisisen Determinasi

\begin{tabular}{lcccc}
\hline \multicolumn{4}{c}{ Model Summary $^{\mathbf{b}}$} \\
\hline Model & $\mathrm{R}$ & R Square & $\begin{array}{c}\text { Adjusted R } \\
\text { Square }\end{array}$ & $\begin{array}{c}\text { Std. Error of the } \\
\text { Estimate }\end{array}$ \\
\hline 1 & $.722^{a}$ & .521 & .512 & 1.416 \\
\hline a. Predictors: (Constant), Kualitas Pelayanan, Sanksi Perpajakan \\
\hline b. Dependent Variable: Kepatuhan Wajib Pajak
\end{tabular}

Sumber: Hasil Pengolahan Data SPSS (2020)

Berdasarkan tabel 10 dapat diketahui bahwa sanksi perpajakan dan kualitas pelayanan mempengaruhi kepatuhan wajib pajak sebesar nilai koefisien determinasi atau $R$ Square yaitu 0.521 atau 52,1\%. Yang artinya variabelitas kepatuhan wajib pajak 52, 1\% dapat dijelaskan oleh sanksi perpajakan dan kualitas pelayanan dan $47,9 \%(100 \%-52,1 \%)$ dijelaskan oleh faktor atau variabel lain.

\section{Pengujian Hipotesis}

Ujit

Tabel 11 Uji t

\begin{tabular}{|c|c|c|c|c|c|c|}
\hline \multicolumn{7}{|c|}{ Coefficientsa } \\
\hline \multirow{2}{*}{\multicolumn{2}{|c|}{ Model }} & \multicolumn{2}{|c|}{$\begin{array}{l}\text { Unstandardized } \\
\text { Coefficients }\end{array}$} & $\begin{array}{c}\text { Standardized } \\
\text { Coefficients }\end{array}$ & \multirow[b]{2}{*}{$\mathrm{t}$} & \multirow[b]{2}{*}{ Sig } \\
\hline & & B & $\begin{array}{l}\text { Std. } \\
\text { Error }\end{array}$ & Beta & & \\
\hline \multirow[t]{3}{*}{1} & (Constant) & 5.011 & 1.459 & & 3.435 & .001 \\
\hline & Sanksi Perpajakan & .283 & .076 & .308 & 3.721 & .000 \\
\hline & $\begin{array}{l}\text { Kualitas } \\
\text { Pelayanan }\end{array}$ & .438 & .071 & .511 & 6.177 & .000 \\
\hline
\end{tabular}

a. Dependent Variable: Kepatuhan Wajib Pajak

\section{Sumber: Hasil Pengolahan Data SPSS (2020)}

Berdasarkan tabel 11 dapat diketahui bahwa nilai Sig untuk Sanksi Perpajakan $(\mathrm{X} 1)$ terhadap $\mathrm{Y}$ adalah $0.000<0.05$ dan nilai $\mathrm{t}$ hitung $3.435>\mathrm{t}$ tabel 1.660, sehingga dapat disimpulkan bahwa $\mathrm{H} 1$ diterima yang berarti terdapat pengaruh X1 terhadap Y. Sedangkan nilai Sig untuk Kualitas Pelayanan (X2) terhadap $\mathrm{Y}$ adalah $0.000<0.05$ dan nilai $\mathrm{t}$ hitung $6.177>\mathrm{t}$ tabel 1.660 , sehingga 
Erika Zahra Afifah Syafira Nasution: Pengaruh Sanksi Perpajakan dan Kualitas Pelayanan Terhadap Kepatuhan Wajib Pajak

dapat disimpulkan bahwa $\mathrm{H} 2$ diterima yang berarti terdapat pengaruh $\mathrm{X} 2$ terhadap Y.

\begin{tabular}{|c|c|c|c|c|c|c|}
\hline \multicolumn{7}{|c|}{ Tabel 12 Uji F } \\
\hline \multicolumn{7}{|c|}{ ANOVA $^{b}$} \\
\hline \multicolumn{2}{|c|}{ Model } & $\begin{array}{l}\text { Sum of } \\
\text { Squares }\end{array}$ & $\mathrm{df}$ & Mean Square & $\mathrm{F}$ & Sig. \\
\hline \multirow[t]{3}{*}{1} & Regression & 211.996 & 2 & 105.998 & 52.837 & .000 \\
\hline & Residual & 194.594 & 97 & 2.006 & & \\
\hline & Total & 406.590 & 99 & & & \\
\hline \multicolumn{7}{|c|}{ a. Predictors: (Constant), Kualitas Pelayanan, Sanksi Perpajakan } \\
\hline
\end{tabular}

Sumber: Hasil Pengolahan Data SPSS (2020)

Berdasarkan tabel 12 dapat diketahui bahwa nilai Sig untuk pengaruh Sanksi Perpajakan (X1) dan Kualitas Pelayanan (X2) terhadap Y adalah $0.000<$ 0.05 dan nilai $\mathrm{F}$ hitung $52.837>\mathrm{F}$ tabel 3.09, sehingga dapat disimpulkan bahwa $\mathrm{H} 3$ diterima yang berarti terdapat pengaruh $\mathrm{X} 1$ dan $\mathrm{X} 2$ secara simultan terhadap Y.

\section{KESIMPULAN}

Berdasarkan hasil penelitian, maka kesimpulan pada penelitian ini adalah Sanksi Perpajakan berpengaruh positif dan signifikan terhadap Kepatuhan Wajib Pajak, Kualitas Pelayanan berpengaruh positif dan signifikan terhadap Kepatuhan Wajib Pajak, dan Sanksi Perpajakan dan Kualitas Pelayanan berpengaruh positif dan signifikan terhadap Kepatuhan Wajib Pajak

\section{DAFTAR PUSTAKA}

Agustini, Komang Dewi, dan Widhiyani, Ni Luh Sari. 2019. Pengaruh Penerapan E-Filling, Sosialisai Perpajakan, Sanksi Perpajakan Terhadap Wajib Pajak Orang Pribadi. E-Jurnal Akuntansi Universitas Udayana Vol. 27.2:19431364

Akbar, M.A, Sebrina, Nurzi, \& Taqwa, Salma. 2019. Pengaruh Kesadaran Wajib Pajak, Sanksi Administrasi, dan Pengetahuan Pajak terhadap Kepatuhan Wajib Pajak. Jurnal Eksplorasi Akuntansi, 1 (1) Seri, 309-319.

Asfa L, Esti Rizqiana dan Meiranto Wahyu. 2017. Pengaruh Sanksi Perpajakan, Pelayanan Fiskus, Pengetahuan dan Pemahaman Perpajakan, Kesadaran Perpajakan Terhadap Kepatuhan Wajib Pajak. Diponegoro Journal of Accounting Vol. 6 No. 3

Bahri, Syaiful, SE, MSA. 2016. Pengantar Akuntansi Berdasarkan SAK ETAP dan IFRS. Yogyakarta: CV Andi Offset. 
Erika Zahra Afifah Syafira Nasution: Pengaruh Sanksi Perpajakan dan Kualitas Pelayanan Terhadap Kepatuhan Wajib Pajak

https://engine.ddtc.co.id/assets/download/peraturanpajak/file/1487738624_L AMPIRAN_per-02_pi_2017.pdf

https://engine.ddtc.co.id/assets/download/peraturanpajak/read/11134

Mardiasmo. 2016. Perpajakan. Jakarta: ANDI

Muhamad, Marisa Setiawati, dkk. 2019. Pengaruh Sosialisasi Perpajakan, Tarif Pajak, Sanksi Perpajakan, dan Kesadaran Perpajakan Terhadap Kepatuhan Pelaporan SPT Wajib Pajak Orang Pribadi. Jurnal Akuntansi \& Keuangan Daerah Volume 14, Nomor 1.

Nafidah, Zumrotun dan Warno. 2018. Pengaruh Sanksi Pajak, Kesadaran Wajib Pajak, dan Kualitas Pelayanan Pajak Terhadap Kepatuhan Wajib Pajak Dalam Membayar Pajak Bumi dan Bangunan. Jurnal STIE Semarang Vol 10 No 1.

Patmasari, Eken, dkk. 2016. Pengaruh Pelayanan, Sanksi, Sistem Perpajakan Kesadaran Wajib Pajak Terhadap Kepatuhan Wajib Pajak Dalam Membayar Pajak Bumi Dan Bangunan. Seminar Nasional IENACO.

Peraturan Direktur Jendral Pajak PER-27/PJ/2016 kemudian diubah menjadi PER-02/PJ/2017 tentang Standar Pelayanan Terpadu Kantor Pelayanan Pajak (KPP)

Pranata, Putu Aditya, dan Setiawan, Putu Ery. 2015. Pengaruh Sanksi Perpajakan, Kualitas Pelayanan, dan Kewajiban Moral pada Kepatuhan Wajib Pajak. E-Jurnal Akuntansi Universitas Udayana 10.2:456-473.

Rahmawaty, Indah. 2017. Buku Praktis Dasar-Dasar Akuntansi. Jakarta Timur: Laskar Aksara

Rochaety, Dr. Eti. 2019. Metodologi Penelitian Bisbis. Bogor: Mitra Wacana Media

Sabet, Eli, dkk. 2020. Pengaruh Sosialisasi Perpajakan, Pengetahuan Perpajakan, Tingkat Pendidikan, Sanksi Pajak dan Kualitas Pelayanan Fiskus Terhadap Kepatuhan Wajib Pajak. Accounting Journal Universitas Yepis Papua Vol 1 No 2

Savitri, Enni, and Musfialdy. 2015. The Effect of Tax Awareness, Tax Sosialization, Tax Penalties, Compliance Cost at Taxpayer Compliance with Service Quality as Mediating Variable. Kuala Lumpur: Procedia.

Simanjutak, Timbul Hamonangan DR, SE, MA dan DR. Imam Mukhlis SE, MSi. 2012. Dimensi Ekonomi Perpajakan dalam Pembangunan Ekonomi. Depok: Raih Asa Sukses.

Susmita, Putu Raraa, dan Supadmi, Ni Luh. 2016. Pengaruh Kualitas Pelayanan, Sanksi Perpajakan, Biaya Kepatuhan Pajak, dan Penerapan E-Filling 
Erika Zahra Afifah Syafira Nasution: Pengaruh Sanksi Perpajakan dan Kualitas Pelayanan Terhadap Kepatuhan Wajib Pajak

pada Kepatuhan Wajib Pajak. E-Jurnal Akuntansi Udayana 14.2:12391269.

Sugiyono. 2017. Metodelogi Penelitian Kuantitatif, Kualitatif, dan R\&D. Bandung: Alfabeta.

UUD Tahun 1945 Pasal 23A tentang Pengaturan Konstribusi Warga Negara dalam Bentuk Pajak

UU KUP Pasal 7 ayat (1) tentang Pengenaan Sanksi Administrasi berupa Denda 